The McCarron Lectures*

\section{Lecture 6: Contemporary Research in Rhetoric/Persuasion}

Gary McCarron

Simon Fraser University
Scholarly and Research

Communication

VOLUME 12 / ISSUE 1 / 2021

\begin{abstract}
A separate strand of rhetoric's development heads in a similar direction as Burke's, but one that focuses specifically on the emergence of what might be seen as a rhetorical science. This lecture looks at the work of Harold Lasswell, Paul Lazarsfeld, Ernest Dichter, and others, who addressed the effects of persuasion through communication research.
\end{abstract}

\section{Résumé}

Il y a une rhétorique distincte qui se développe dans une direction semblable à celle prise par Burke tout en se focalisant sur l'émergence de ce qu'on pourrait qualifier de science de la rhétorique. Ce cours porte sur l'œuvre d'Harold Lasswell, Paul Lazarsfeld, Ernest Dichter et d'autres qui ont étudié les effets de la persuasion en faisant de la recherche en communication.

\section{Keywords / Mots clés}

Contemporary research; Harold Lasswell; Paul Lazarsfeld; Ernest Dichter / Recherche contemporaine; Harold Lasswell; Paul Lazarsfeld; Ernest Dichter

\section{Introduction: Art versus science}

This lecture examines how current ideas about rhetoric have changed from the notions embraced by previous generations, particularly how rhetoric diverged in becoming modern. One strand in the development of rhetoric leads to the work of Kenneth Burke and others like him. A separate strand heads in a similar but different direction under the influence of empirical methods and procedures. Given that we have already discussed Burke in detail, I want to look at the other development in rhetorical studies: the rise of a positivist attitude toward the study of persuasion. This means leaving behind the literary tradition, with its litany of philosophical ideas and debates, and focusing specifically on the emergence of what might be seen as a rhetorical science.

As mentioned in Lecture 5, the so-called new rhetoric took rhetorical analysis down a more literary avenue; however, other changes associated with the rise of the modern
Gary McCarron is Associate Professor in the School of Communication at Simon Fraser University. Email: gmccarro@sfu.ca

* Please see Editorial: Syntheses, Reflections, and Conjectures in Scholarly and Research Communication: $\mathrm{SRC}^{1+1}$.

* These lectures are provided with the understanding that when used in class you consider fair use, providing a payment of $\$ 10$ per student. These funds will be forwarded to the author. Please contact Marilyn Bittman, Managing Editor, SRC, for further payment information: bittmanme @shaw.ca 


\section{Scholarly and Research}

\section{Communication}

VOLUME 12 / ISSUE 1 / 2021 state also greatly affected the way rhetoric was studied and understood, including a development in our ideas about the nature of the rhetor and our conception of the audience. Focus on the individual rhetor shifted to the idea that those doing the persuading were corporations, advertising firms, or politicians and their spin doctors. This does not mean that we have lost all interest in the individual person speaking in front of an audience. It just means that there slowly emerged a broader conception of the social role of the rhetor, someone who can be a disembodied voice, an anonymous news source, or an invisible agent. In addition, our idea of the live audience has also changed greatly. With the rise of newspapers, the development of radio, the advent of television, and the more recent arrival of digital culture, the notion of the audience has become increasingly abstract and diffuse. This abstraction of the audience seems, on the surface, to be problematic, for if we know little of our audience, how can we possibly be persuasive? In the philosophical tradition, after all, we know that Aristotle was concerned about pathos, about the emotional disposition of the audience as central to the way rhetors constructed their messages. In the absence of those kinds of cues and markers, how does the rhetorical procedure work?

The main answer is that we now tend to aggregate total responses and consider the audience as having a kind of collective mind, a mind often regarded as a black box. And when we accept this model, it makes sense that would-be persuaders are not terribly concerned with understanding what is going on inside that box; their only concern is to provide the appropriate information as input that will get the desired response as output.

This point has been turned into a critique of big data by some writers, but while I might share some of those concerns, that is not my primary interest here. While the aggregation of responses according to algorithms designed and operated by digital devices has provoked many progressives to alarm, and while I recognize that these problems warrant thorough study and criticism, I will remain more or less neutral here. I want to present some of the key moments when rhetoric changed from an art to a science without getting too weighed down in critical commentary. ${ }^{1}$

Aristotle suggests that the ancients were concerned with finding the available means of persuasion in any given situation because they were interested in the way rhetors might go about their task of gaining compliance in order to make a successful rhetorical appeal. But we also know from Socrates that many of these same scholars were concerned that several other considerations had to be taken into account. Two were preeminent: truth and morality. Recall that Socrates criticized Gorgias for ignoring both. Socrates, on the one hand, was particularly concerned that the skilled public speaker would ignore the truth in pursuit of victory, even to the point of ensuring that an unqualified person would gain an important social position, such as the post of a medical doctor. On the other hand, Gorgias was unabashedly proud of his ability to teach the techniques that would allow such a thing to happen. Socrates thought this was despicable, and various ethical debates have raged within the field of rhetoric ever since.

In fact, contemporary discussions of rhetoric continue to raise moral questions rather frequently. These questions come in various guises, but one of rhetoric's persistent and largely unresolved moral conundrums concerns the goals of persuasive discourse, the

McCarron, Gary. 2021. Lecture 6: Contemporary Research in Rhetoric/Persuasion. Scholarly and Research Communication, 12(1). doi:10.22230/src.2021v12n1a373 
same problem the Greeks found so vexing. Today, this moral problem usually assumes a different appearance and comes to us, unsurprisingly, in the sphere of consumerism. What do I mean by this?

One of the central moral questions in consumer studies concerns the problem of needs versus wants, and in particular, the use of rhetorical appeals to convince people that what they want is really something they need. There are related questions to be considered, too, such as whether our needs are even susceptible to persuasion in the same way our wants are. This is a point that takes us back to Plato's divided line of knowledge and the differences he argued kept the intelligible and the lower realms forever separated. The confusion between wants and needs has a similar profile. Moreover, the relation between wants and needs is a tricky one, for there is nothing entirely immutable about the distinction. Nonetheless, the key question scholars in consumer studies examine is whether it is possible to apply persuasive discourse to the material, spiritual, and psychical needs that sustain us. The corollary, then, is to ask whether persuasive discourse is only effective in the case of our wants.

You will note that this modern question reflects Aristotle's claim that no persuasion is required to understand the truths of geometry, for these truths do not change according to how someone might apply rhetoric. That is, some things simply transcend the need for persuasion because they are matters of fact; to some extent, this argument reappears today in the way we conceptualize the difference between wants and needs. For example, are our wants not merely unimportant and superficial, whereas our needs are important and essential? On one hand, we need food, water, and shelter, and no rhetorical pleading would seem to be required to make this apparent to us. On the other hand, we do not need iPads, cellphones, and heated leather seats, and, thus, rhetoric comes into play in order to sell these items to us. What is really happening, however, is that marketers are selling us on the idea that these wants are actually needs. And since the notion that marketers and others working in that field convert wants into needs, we can see that the connection to the Platonic complaint that sophistical arguments comprise deception, distraction, and falsity could equally be applied in contemporary settings.

Questions about the morality of persuasion are often brought forward in connection with the idea that rhetoric, much as Plato argued, becomes a self-serving and insular form of discursive practice that aims to accomplish a number of unsavoury goals, such as encouraging people to buy things they do not need, maintaining the social and political status quo, and distracting jurors from evidence in order to direct their attention to legally irrelevant considerations. In short, to lead us away from the truth. In one sense, then, we can note that one of the most essential points about philosophical discussions of rhetoric concerns the relation between certainty and contingency. What is certain is truth, and in this case of human lives, this includes our basic needs. What is contingent, however, is the merely probable, and this could include the scores of things we want. Plato tried to schematize this distinction by placing them on different sides of his famous divided line. Rhetoric only is effective-when it is effectivewhen dealing with things on the lower side of the line, such as conjectures and opinions. Persuasion plays no part in the intelligible order, for on that side of the line is conviction, not rhetoric. 


\section{Scholarly and Research}

\section{Communication}

VOLUME 12 / ISSUE 1 / 2021
Francis Bacon (1973) also worried over this problem of how best to balance affection and reason, eventually deciding that rhetoric was necessary as a kind of self-persuasion to keep things moving properly. Bacon believed that we use rhetoric on ourselves to keep things from sliding into the abyss of unbridled sensuality. That is, we apply our reason as a check on our imagination to keep our willpower from overruling our higher-level cognitive reasoning. Our affections are so poor at maintaining a sense of proportion that it is only through self-persuasion that we can align our long-term interests with the good of society. ${ }^{2}$

In light of this argument, is it possible to say that rhetoric is now associated with conviction rather than mere persuasion? This may seem like an odd question, so let me put it more concretely: is rhetoric still an art, or has it become a science? One way to consider this question is to note that rhetoric maintains a precarious balance between art and science. Everyone knows that advertising works only 50 percent of the time and that the biggest difficulty is that no one knows which 50 percent is which. In other words, there is a tug of war today concerning the status of rhetoric-a debate about whether rhetoric is the art of persuasion or the science of compliance. This is not to argue that we have completely lost sight of the idea that rhetoric has its artistic elements, for we often think about discourse in terms of its artistic and even poetic aspects. We can also look at Aristotle's work, however, as a highly systematic organization of the various techniques of persuasion that helped to set the stage for later examinations that focused principally on rhetorical activities as the enactment of an objective scheme. Indeed, beginning with Aristotle, the push to systematize rhetorical practice pointed to the future development of elaborate techniques that would come to characterize persuasion as amenable to more empirical and practical measures. Just as the study of signs can yield the art of iconography, so too can it lead to a science of semiotics. And it is no different with rhetoric. While there were powerful voices arguing for the idea that rhetoric can deal with only that which is contingent and, therefore, must be regarded chiefly as an artform, more powerful voices began to suggest that the techniques rhetoricians had identified could be codified, studied, and tested empirically to determine the best means of persuasion. Aristotle had called the search for the best means of persuasion an art; slowly, it became a science.

There is little doubt that the artistic or creative element of persuasion went into abeyance for a while with the arrival of the scientific conception of persuasive communication. Even today, the so-called creatives who work at advertising firms tend to occupy the lowest station in the company hierarchy, with the highest salaries going to the account executives, the people who actually manage the business of the campaigns. So while I am not suggesting that the artistry of rhetoric has disappeared entirely, I am saying there was a decisive shift in professional attitudes about persuasion and rhetoric that was connected to broader changes in our ideas about human nature.

\section{The rise of positivism}

By the start of the twentieth century, the relationship between communication studies and the social sciences was unified by an overriding interest in empirical research. That is, communication studies - which included the study of persuasion-was placed on a different level from its former station as one of the arts. This transformation in the way

McCarron, Gary. 2021. Lecture 6: Contemporary Research in Rhetoric/Persuasion. Scholarly and Research Communication, 12(1). doi:10.22230/src.2021v12n1a373 
that communication and rhetoric was studied was part of a much broader change in Western attitudes generally, as the focus of the so-called human sciences (including history, linguistics, and psychology) became oriented toward positivism. Positivism is a theory that contends that true knowledge is only possible if we follow the observational methods copied from the physical sciences. Thus positivists say that what counts as knowledge must be derived from sense experience. There were many important contributors to positivism, but the idea is most commonly associated with the French sociologist Auguste Comte (1798-1857). Comte's theory, which was also called positive philosophy, was both a theory of knowledge, as I have just described, and a historical conception of civilization. Comte believed that human societies went through three stages. The first is the theological state, in which humans progress from fetishism to polytheism to monotheism. This is the most primitive state of social life. Next comes the metaphysical state, in which the idea of God and the supernatural are cast off. Instead of seeking divine causes, people in the metaphysical stage of cultural development focus on natural powers and properties to explain things. Finally, we arrive at the positive state of human cultural and social development. At this stage, Comte says we abandon all interest in questions of why and instead ask only how. In other words, positivism rejects the notion that there are any real human or social sciences at all, for these disciplines-history, for example, and certainly rhetoric-have no claim to being scientific in the strict sense Comte advocated. ${ }^{3}$

In the opening decades of the twentieth century, the rise of positivism was something of a rallying cry for a wide range of academic fields in the historical and human sciences. Whereas psychoanalytic approaches to the study of human nature were still in vogue, in the United States there was a growing consensus that behaviourism, with its reliance on strictly empirical methods, was the preferred method for analyzing the mind. Indeed, despite the fact that Freud was against training medical doctors to be certified as psychoanalysts-because he thought that doctors were too beholden to a scientific paradigm that was incompatible with the anthropological and humanistic background he preferred for his followers-the American Psychoanalytic Association decided to restrict psychoanalytic training to medical practitioners! Moreover, the turn to behaviourism was also a turn to the theory of the black box or, in Comte's sense, a turn to how rather than why.

Another example of this widespread adoption of positivistic methods is the Flexner Report of 1910. Commissioned by the Carnegie Foundation, the report was designed to standardize medical practice in Canada and the United States, and sweeping changes to medical training were enacted after its release. The report's main findings suggested that medical practice should be standardized in universities and that doctor training should move away from the arts entirely and into the biological sciences. Needless to say, there were great advantages to this approach, but it should be equally obvious that the results were problematic. It was later determined that the entire exercise had been driven by specific political interests. But whether the Flexner Report was of absolute benefit to medical science or presented a range of unanticipated problems is not my concern at present. I am just trying to highlight how the reorganization of the study of human nature in the beginning of the twentieth century was based on a fundamental shift toward empirical, scientific, positivistic views of behaviour. ${ }^{4}$
VOLUME 12 / ISSUE 1 / 2021 


\section{Scholarly and Research}

\section{Communication}

VOLUME 12 / ISSUE 1 / 2021

\section{Making persuasion scientific}

The study of persuasion was no exception to this growing fascination with empirical measurement. Going back least as far as Bacon, people had shown a keen interest in the idea that the study of human nature could include the study of rhetorical practices. It was not really until the beginning of the twentieth century, however, that we witnessed an increasing interest in the science of persuasion, especially as that interest began to crowd out other ways of thinking about persuasive communication. It is as if the eloquence of rhetoric was replaced by the priming effects of behaviour modification. This is largely because of the influence of research that was carried out in order to determine how best to manage public opinion following World War I.

I want to look at these changes and developments by considering a series of researchers whose work was important in making rhetorical analysis accountable to the positivistic view of human nature that was growing in power. I will focus on specific aspects of their work that figure into a discussion of the way rhetoric was co-opted for science. In each case, though, I will deal with what is generally thought of as each researcher's most significant contribution to communication research.

\section{Harold Lasswell}

One of the earliest researchers in this sphere was Harold Lasswell (1902-1978). Lasswell had considerable influence on Kenneth Burke, though the two were not close friends, and Burke took pains to distinguish his more literary approach from Lasswell's positivism. Burke recognized that they were dealing with similar sets of ideas, but he was not impressed with the work Lasswell undertook. Of course, in the end, Lasswell became the far more famous figure in communication research.

Lasswell's (1927) book Propaganda Technique in the World War displays one of the earliest examples of instrumental thinking in communication studies. Specifically, Lasswell was the first to describe the mass media as a hypodermic needle that could inject ideas directly into the consciousness of each audience member or citizen. This was certainly a far cry from Aristotle's idea that rhetoric was a search for the available means of persuasion, for Lasswell was more interested in effects then he was in the human aspect of persuasive practice.

Lasswell noted that great strides had been made in the technology of communication (telegraphy, radio, cinema), and he felt it was incumbent on the government to use these resources appropriately to ensure that people got the message that the government needed (or wanted) to inject into its citizens. Indeed, he argued that propaganda and democracy are synonymous, a point that likely sounds peculiar. The point is that it is necessary from time to time to keep people aligned with those values and attitudes that a democratic polity believes is crucial to the health of the nation. Hence, it might be useful to remind people through blitz advertising or other forms of mass communication of just how lucky they are to be living in a democracy. In Lasswell's view, the population - or the audience, really - was a passive target, capable of being influenced by a message that, if properly crafted, could be inserted directly into the psyche of each of the recipients. 
The audience, then, was regarded in Lasswell's work as undifferentiated and passive, a rather different conception of the audience that we find in Aristotle or even in Isocrates and the other sophists, who were well versed in the notion that audiences are made up of individuals with varying dispositions, opinions, and values. How did this attitude about audiences come about? Again, the key thing to bear in mind is the shift toward a scientific methodology in the social and human sciences, which is most successful when it regards people as objects rather than as subjects. Historically, the tendency was, in many respects, to treat people as machines-very complex machines, of course-but machines, nonetheless. Hence, research focused on things such as the behaviour of crowds, pioneered by Gustave Le Bon (2002); behaviourism, which was inaugurated in 1914 by John B. Watson (1913) and called the mind a black box; the theories of Ivan Pavlov (2015), which dealt with various forms of conditioning in order to get desired responses; and the work of British psychologist William McDougall (1920), a pioneer in social psychology whose work focused on the idea that only certain primitive impulses or instincts could explain the acts of humans and animals. In other words, the opening decades of the twentieth century saw the development of a wide variety of approaches that were indebted to empirical methodologies and inspired by the natural sciences applied to the direction and manipulation of the conduct of everyday citizens.

The turn to empiricism in communication studies was situated largely in the field of persuasion, particularly propaganda. It was thought by many researchers of the time that the shaping of public consciousness - what Edward Bernays (1923) would call the crystallizing of public opinion - was a necessary function of the democratic state. Indeed, it is significant that between the 1930 os and the 1950s, the communication landscape became deeply propagandist in character. Obviously, Nazi and fascist propaganda were quite different from North American advertising and marketing, but there were some similarities, too. On both fronts, as Lawrence Samuel (2010) has argued, there was a preeminent concern with efficiency, consensus, and control, a drive to bring order out of chaos, as Bernays called it, whether for militaristic or consumerist purposes. This was a time when the word propaganda did not carry all of the negative meaning it has today, and while it communicated a belief in the value of uniformity of thought, it was not necessarily regarded as entirely negative. Conformism cycles in and out of favour throughout history, and this period was certainly one where conformist attitudes were taken as a symbol of one's patriotic commitment to the good of the nation.

Lasswell became involved in the 1930 s with government efforts to keep public attitudes in line with prevailing politics. When President Franklin D. Roosevelt was elected in 1932, the Great Depression had America in its grip, and so he introduced his famous New Deal policies to get the country out of its economic stagnation. But the New Deal involved the development of what most today would call the welfare state, and there was concern in government circles that many Americans would resist policies that smacked of socialism or, worse yet, communism. So Roosevelt asked Lasswell to help him by lending his skills to shape public opinion. People were to be persuaded of the correctness of certain policy initiatives through constant opinion sampling followed by modifications to message delivery to ensure that specific elements of the government's message were broadcast while others were kept less obvious. Opinion polls soon became tools for the day-to-day management of public affairs and have pretty much 


\section{Scholarly and Research}

\section{Communication}

VOLUME 12 / ISSUE 1 / 2021 remained so. Roosevelt was re-elected in 1936, as public opinion polls predicted, and by 1937, the American Association for Public Opinion Research had been founded. Its flagship journal, The Public Opinion Quarterly, is still published today. ${ }^{5}$

In essence, Lasswell's was a functionalist account that saw the media as serving a specific function within the greater organic totality of society. In other words, he was regarded by the federal government as someone whose methods and insights allowed lawmakers in Washington to apply techniques that would produce outcomes favourable to chosen policies. And this was possible not in spite of Lasswell's focus on largescale audiences rather than individuals but precisely because of it. That is, Lasswell was interested in getting results without concerning himself with the details of why people responded one way rather than another. Like Plato's Gorgias, he was keen to use persuasive techniques to manipulate without being particularly concerned about the moral or epistemological issues involved. Hence, it is no surprise that as his reputation increased, he found himself being approached by non-governmental entities to conduct research. Corporations, in particular, were keen to employ Lasswell to help them discover what sorts of information an audience needed from the sponsor in order to ensure that the message received was the message they sent. Marshall McLuhan's claim that the medium is the message was still some years away, but Lasswell was making headway toward realizing a similar notion: that the content of the message was less important than the manner in which it was communicated-and this was especially true if the focus was to get measurable results. Hence, Lasswell (1948) came up with his famous definition of communication to capture the spirit of his work: who says what, in which channel, to whom, and with what effect?

Lasswell formulated the study of communication chiefly in terms of an impact orientation, and it was this way of analyzing the media that governed how researchers would proceed for years to come. Consider, for instance, when Orson Welles broadcast his famous War of the Worlds on CBS radio on October 30, 1938. Thousands of Americans ran into the streets-many with towels on their heads-in a condition of sheer panic. Welles was forced to offer an apology on the program the following evening, and the story was even made into a film. But what is most interesting is that researchers in the social psychology of persuasion were utterly captivated by the idea that everyday citizens were so gullible that a radio show fooled them into believing their planet was under attack by beings from Mars, and so the psychologist Hadley Cantril (1982) and his associates set about studying the events of that night in order to determine how best to explain the mechanisms by which people were so readily persuaded by a message that most of them would likely have recognized as a farce if there had been time for critical reflection. Scientific investigators, in other words, were enthralled by the idea that you could get people to believe anything, that you could convince them of the most outlandish tales, and that you could persuade them to engage in utterly uncharacteristic forms of behaviour, if you only had the appropriate psychological key with which to unlock their psyches.

\section{Paul Lazarsfeld}

There were other important researchers in addition to Harold Lasswell working in this same tradition, including Paul Lazarsfeld and Robert Merton. I will not go into great 
detail about Merton but I do want to say a couple of things about Lazarsfeld in order to give some additional depth to our understanding of this period.

Lazarsfeld is widely regarded as the founder of motivation research, an approach to understanding and manipulating audiences that drew more heavily from Freudian psychology than Lasswell's work did. In fact, whereas the Nazis were interested in group psychology, psychoanalysis was the trend in other centres in Europe, particularly Vienna, where Freud was based.

Lazarsfeld described his "discovery" of motivation research as having occurred on a single day in Vienna in 1930. He was a young psychology professor working at the university when the owners of a new laundry service asked his advice to help them improve their business. Lazarsfeld took on the assignment, and in the course of interviews, he discovered that many Austrian women were reluctant to send out their laundry because it was regarded as reflecting negatively on their status and prestige as women capable of looking after their homes. (Lazarsfeld describes their concern as an insult to their role as a proper hausfrau.) But when he talked to women who did use the laundry service, he discovered that they had often sent out their laundry during a time of crisis, such as when a child was sick or houseguests unexpectedly dropped in. In other words, they had sent out their laundry because some sort of emergency had prevented them from following their usual household schedule and they needed some assistance. However, sending out their laundry that single time showed them how convenient it was; thus, they were more likely to become regular customers afterward. The key, it seemed, was to somehow get them to send out their laundry once and hope that the convenience factor would lead them to continue with the practice. ${ }^{6}$

What did Lazarsfeld do once his research had revealed the various pieces of the puzzle? He suggested that the owners of the laundry look through the obituary sections of the local papers to identify households in the midst of a crisis and then send a brochure to those homes. His assumption was that the bereaved would find it difficult to keep up with the laundry in the midst of grieving. It was a cynical, and some might say cruel, proposition but it paid off handsomely, leading to a large increase in the laundry's customer base. It was also the defining moment for Lazarsfeld, inasmuch as he had made evident the enormous power of motivation and manipulation.

In the beginning, Lazarsfeld called his tactic the psychological approach, but it soon became known as motivational research in order to distinguish his work from run-ofthe-mill psychology. He recognized, of course, that what he was doing was ethically ambiguous, but his success with the Viennese laundry soon brought him to the attention of other organizations and companies; this fame and the prospect of a lucrative career helped him to deal with the moral problems he faced. That same year, still in Austria, he was hired to do research on people's soap preferences and also to conduct surveys of radio listeners. His findings were always interesting and sparked new avenues for motivational research. In his studies of radio listeners, for instance, he found that they tended to be working-class people who preferred strong-smelling perfumes and had a particular liking for chocolate. His reason was that working-class citizens were "starved for pleasure" and chocolate and perfume helped to offer some satisfac- 


\section{Scholarly and Research}

\section{Communication}

VOLUME 12 / ISSUE 1 / 2021 tion. But was Lazarsfeld right? Were working-class Austrians in the years before the Anschluss starved for pleasure? Ultimately, it did not matter whether his explanation was factually correct. What mattered was that he had discovered an exploitable connection, a target audience that could be addressed with marketing messages in order to extract sales. The simple fact that working-class Austrians liked chocolate was really all that mattered, for that piece of information could be transformed into profits. Why did they like chocolate? It did not really matter.

In 1933, Lazarsfeld completed a study of unemployed workers that attracted the attention of the police owing to two things: the fact that his political orientation was largely socialist and the rise of Nazism in Austria. Recognizing that he could easily be in danger for his politics, Lazarsfeld relocated to America on a two-year leave sponsored by the Rockefeller Foundation. In his official documentation, he referred to himself as a Marxist on leave. But when the two-year funding ended, it was clearly unsafe for Lazarsfeld to return to Austria, the annexation of Austria was only three years away, and he stayed in the United States.

What Lazarsfeld brought with him to America was a well-trained mind versed in the latest empirical research. While in Europe, he had been an associate of the thinkers identified as the Vienna Circle, which meant that he had considerable exposure to the philosophy of logical positivism. He also had been trained in experimental research, and shortly after arriving in the United States, he began teaching at Columbia University, where he established the Bureau of Applied Social Research in 1941. ${ }^{7}$ In 1938, Lazarsfeld was put in charge of the Princeton Radio Project along with Frank Stanton, a psychologist who was the director of research for the CBS radio network. Stanton later became the president of CBS when it began television broadcasting.

Working together, Lazarsfeld and Stanton began a series of experiments studying radio audiences. They designed a programme analyzer or profile machine to record listener reactions in terms of interest, dislike, or indifference. Listeners expressed their satisfaction by pressing a green button held in their right hand and dissatisfaction by pressing a red button held in their left hand. Pressing neither button meant indifference. The buttons were connected to a mechanism that used a stylus to record the highs and lows of listener reactions on a revolving paper cylinder. Christened the Lazarsfeld-Stanton Program Analyzer, the process was soon adopted by specialists to analyze the reactions of cinema audiences. It is still used in focus groups today, although it is now a computerized process.

What is interesting about this work is not just that it prefigured the mania for audience measurement - a fascination that goes on today at all levels of management in the media industries - but that it helped to make the quantitative measurement of audience reaction more significant than the qualitative reactions of individual audience members. For Lazarsfeld and his followers—and the sponsors funding his research-it was all a matter of discovering how best to persuade large groups of people rather than how best to persuade individual listeners. This is significant in that it shows how managerial practices can move away from an interest in the human aspects of rhetoric and persuasion and into another area entirely: the aggregate response. In other words, the investigators no longer need to know exactly why an effect is working, they only need

McCarron, Gary. 2021. Lecture 6: Contemporary Research in Rhetoric/Persuasion. Scholarly and Research Communication, 12(1). doi:10.22230/src.2021v12n1a373 
to repeat the message to see if they get the same effect a second time. This is a legacy of the behaviourist approach in which what actually happens in the black box of the mind is unimportant. All that matters is the behaviour that results when people are placed in specific situations and contexts. Hence, the famous behaviourist B. F. Skinner called for a technology of behaviour.

Lazarsfeld became well known for the idea of administrative research. This referred to his belief that the goal of any so-called science of society could not be-should not be-to build a better society since the existing democracy of the United States had attained perfection. This seems like a peculiar thing to hear a scientific researcher claim, but two important factors conditioned his thinking. First, you will recall that he was a European émigré whose disdain for totalitarian politics strongly predisposed him to view his new home as above reproach. Second, Lazarsfeld was devoted to the empirical tradition in science, and so he subscribed to the view that science was ultimately neutral. Hence, administrative research referred to the task of conducting research on persuasion for both corporate and governmental media managers, who Lazarsfeld believed were free of any specific political biases.

\section{Two-step flow model of communication}

Lazarsfeld's research was important to people working at different levels of government and to managers in the commercial and corporate sectors. As this work continued, Lazarsfeld and his colleagues had something of a breakthrough in the discovery of what eventually became known as the two-step flow model of communication. This model challenged Lasswell's mechanistic account of communication as direct and undifferentiated (the hypodermic model) by emphasizing the role of opinion leaders (the primary group) in message dissemination and delivery. In other words, communication was now thought to follow two steps. The first step involved people who were relatively well informed because of their direct exposure to the media; the second step involved people who had less contact with the media and depended on others for information.

Even today, field researchers set out to discover the opinion leaders in the youth culture in the domain of fashion and then try to copy the styles these young people have developed in the commercial marketplace. Modern researchers often use the expression "early adopter," which actually comes from the work of Lazarsfeld and his associates as they developed the two-step flow model of communication. During the 1960s and 1970s, Lazarsfeld's work was taken up by the United States State Department and educational foundations to spread ideas in the Third World, including birth control methods, farming techniques, and so on. In other words, persuading people in nonWestern countries to accept the march of modernization meant finding people in various communities whose reputation and stature made them opinion leaders. A central figure in this area was Everett Rogers (1962), whose book The Diffusion of Innovation spelled out a strategy for international development-which some would call colonialism-that included the dividing of peasants into five categories: innovators, early adopters, early majority, late majority, and laggards.

The two-step model, and Lazarsfeld's work in general, did not remain ensconced in the academy, nor was it restricted to government agencies. Market specialists became

McCarron, Gary. 2021. Lecture 6: Contemporary Research in Rhetoric/Persuasion. Scholarly and Research Communication, 12(1). doi:10.22230/src.2021v12n1a373 


\section{Scholarly and Research}

\section{Communication}

VOLUME 12 / ISSUE 1 / 2021 increasingly aware of what Lazarsfeld was up to and decided that the work he was doing could easily be adapted to consumer marketing. Why just persuade policy wonks when you could use those rhetorical skills to make money? In fact, marketing people began to notice some significant overlap between the models they were using and some of the ideas put forward by Lazarsfeld and his colleagues. Eventually, the Bureau of Applied Social Research became involved in numerous studies on products, including cosmetics, toothpaste, soap, instant coffee, and men's clothing. Students trained by Lazarsfeld became the gurus of the advertising industry.

\section{Ernest Dichter and a couple of others}

One of Lazarsfeld's students, Ernest Dichter, rose to such prominence in the field that he became known as the "father of motivational research." Another of his students, Herta Hertzog, was hired by a large New York advertising firm and became a major figure in consumer motivation research.

Dichter is an especially interesting person in the history of the shift to positivism in marketing. He helped to promote a number of well-known products and services, including the Barbie doll line. ${ }^{8}$ As a student of Lazarsfeld, Dichter had many of the same intellectual foundations. Whereas Lazarsfeld remained a lifelong Marxist, however, Dichter was enthusiastic about capitalism and consumerism. He is often seen as one of the key figures behind the post-war economy, as he argued that America could only advance economically if people recognized that the production economy that had arisen during the war needed to evolve into a consumption economy. But what chiefly set Dichter apart was his focus on emotions.

Dichter often wrote about the influence of Aristotle and Plato on his marketing strategies, but he claimed that where he differed was in shifting from the leading role of reason to the leading role of irrational impulses and unconscious desires-in short, emotions. Dichter thus pioneered the use of various psychological tests in market research, especially those tests that tapped into peoples' emotional lives, such as the Rorschach ink block. Where most market research reports were filled with statistical tables and charts, Dichter's were comprised of stories, off-the-cuff impressions, verbatim quotations from his interview subjects, and even doodles that came to him during the course of an interview. His approach to information gathering and report composition was completely non-linear. This meant, among other things, that he told companies to break down the us-versus-them mentality that ruled in most marketing circles and adopt a partnership model instead. So, when ESSO wanted to market their new gasoline formulation as having a "high octane rating," Dichter interviewed everyday people and suggested a different slogan: "Put a tiger in your tank!" He understood the visual dimensions of rhetoric, in other words, and also recognized the power of the image as a form of syllogistic logic (he knew his Aristotle). Dichter helped banks devise a new strategy to get people to borrow money by calling it overdraft protection; he was the person who came up with the idea of the car clock because drivers like to know how fast they are going in real time, not just in miles per hour. He even followed Lazarsfeld's lead in interviewing women about household economies and discovered, among other things, that many women-and women did all of the grocery shopping in those days-were reluctant to buy candy as it made them feel like a failure as a parent.

McCarron, Gary. 2021. Lecture 6: Contemporary Research in Rhetoric/Persuasion. Scholarly and Research Communication, 12(1). doi:10.22230/src.2021v12n1a373 
He suggested that all candy products be moved near the cash register so that candy would be an impulse buy, thereby alleviating the sense of guilt. He always said that marketing potential must be reaped from desire.

Many other researchers followed in Lazarsfeld's footsteps or were directly influenced by his work because they were his students or colleagues. Aside from Dichter, one of the more famous was Carl Hovland, a psychologist who adopted Lazarsfeld's behaviourist approach for his studies in persuasion. Hovland conducted experimental studies on persuasion during World War II, using American soldiers as his subjects. His research focused on measuring the effectiveness of Allied propaganda on troops' morale, the extent to which they were informed about their duties, and their attitude in combat. After the war, these experiments gave rise to a set of research projects on methods for improving the effectiveness of mass persuasion. Under Hovland's direction, the research focused on what happens when the image of the communicator is varied, the nature of the content of messages, and the situation in which the audience was placed (in other words, his work addressed the standard Aristotelean themes of ethos, pathos, and logos). For instance, Hovland and his associates found that the credibility of the communicator was important in influencing audiences: the more prestigious the speaker, the more likely he or she is to be believed. In the case of content, they discovered a number of things. For instance, in one experiment, they divided a group of school-age children into four groups. One group received a lecture promoting toothbrushing that included a major fear appeal (images of decaying teeth and discussions of the possible consequences of bad dental hygiene, including blindness, cancer, and paralysis). The second group received a moderately fear-inducing lecture that discussed things such as mouth infections and sore swollen gums. The third group received a minimal level of fear inducement with some discussion of decayed teeth and cavities. The fourth group received no lecture at all.

The findings showed that although all three lectures had some effect, the strong appeal (the most fear inducing) was less effective than the more moderate presentations. The minimal appeal had the greatest effect on getting children to brush their teeth; the lecture with the greatest fear appeal had the smallest effect. The conclusion that Hovland and his associates drew was that strong fear raises strong defences and thus prevents attitude change.

The shift from rhetoric to (scientific) persuasion signalled a coterminous shift toward a model of empirical quantification. It also meant a shift toward outcome-based research projects that focused on the explication of techniques for manipulation. In a very real sense, outcomes were also important to the sophists, so it might be suggested that the only important change from the time of Pericles to the time of Lazarsfeld was a change in the mode of understanding that compliance professionals focused on-a change, that is, from art to science.

\section{Cognitive dissonance}

One of the theories that communication theorists began to employ was the theory of cognitive dissonance. The idea of cognitive dissonance was not directly influenced by Lasswell, Lazarsfeld, Dichter, or Hovland but it certainly was consistent with the essential ideas 


\section{Scholarly and Research}

\section{Communication}

VOLUME 12 / ISSUE 1 / 2021 forming the intellectual background of the era. Formulated by Leon Festinger (1957) in the mid-1950s, the theory states that when there is a discrepancy between your beliefs and your actions, you will experience a state of cognitive dissonance. That is, there will be an inconsistency between belief and behaviour, and this inconsistency will be experienced negatively. To put this yet another way, if you have information (or beliefs) that is insufficient to justify a particular action/behaviour and yet you do that action/behaviour, then you might experience dissonance, a feeling of inconsistency between what you know and what you have done. Festinger's research was initially conducted among the members of a cult-like community whose leader was convinced that interplanetary beings were preparing to bring about the end of the world. When Prophecy Fails (Festinger, 1956), which chronicles the rise and fall of an American apocalyptic group, is one of the classic texts in twentieth-century social psychology. The text begins with an unusual opening for a scientific study, a sort of invitational challenge to the reader:

A man with a conviction is a hard man to change. Tell him you disagree and he turns away. Show him facts or figures and he questions your sources. Appeal to logic and he fails to see your point. (p. 3)

From these sorts of quotidian observations concerning the difficulties of persuasion, Festinger proceeds to develop what has become a central principle in social psychology, the theory of cognitive dissonance. Let me give you one of Festinger's other, less esoteric examples to show more clearly how the theory operates.

Imagine that a young man purchases a car costing more than he originally intended to spend. The car is stylish and fast, however, and he has convinced himself that the price is redeemed by these qualities. But following his purchase, he is dismayed to discover that several things go wrong with the vehicle. Moreover, it turns out that repairs are more expensive than he expected. He further discovers that his friends believe he was unwise to spend so much on the car, a judgement made worse by the fact that many of his friends deem the vehicle "ugly." Now, if the dissonance becomes sufficiently high, he may opt to change his behaviour and sell the car, even if it means taking a financial loss. In selling the car, however, he will at least achieve dissonance reduction because he will no longer be burdened with an expensive and unreliable vehicle. He will also be free from the sarcasm and rebukes of his friends.

Festinger then asks what happens if the dissonance the new car owner experiences is not severe but moderate? What if the dissonance does not rise to a level that persuades him to get rid of the car? In short, what if he can reduce the dissonance without changing his behaviour? In this case, Festiner (1957) postulates, the new owner

could keep the total dissonance low by adding more and more cognitions that are consonant with his ownership of the car. He begins to feel that power and riding qualities are more important than economy and looks. He begins to drive faster than he used to and becomes quite convinced that it is important for a car to be able to travel at high speed. With these cognitions and others, he might succeed in rendering the dissonance negligible. (p. 29)

With this strategy, the young man achieves dissonance reduction and manages to keep the vehicle. That is, he changes his views about what qualities he values in a car and

McCarron, Gary. 2021. Lecture 6: Contemporary Research in Rhetoric/Persuasion. Scholarly and Research Communication, 12(1). doi:10.22230/src.2021v12n1a373 
thereby brings his cognitions in line with his purchasing behaviour. Hence, there is no longer an appreciable and uncomfortable difference between how he acted and what he believes - or, at least, this is what he manages to achieve by reordering his priorities as they relate to the purchase of an automobile. This process of dissonance reduction is really at the heart of cognitive dissonance theory. Whenever we have acted in a way that is not consistent with our beliefs-whenever our behaviour and our cognitions do not match -we risk the experience of dissonance and will seek out ways of reducing that dissonance. For instance, in keeping with the theme of car purchases, consider that studies show people read new-car advertisements more often in the days and weeks immediately following an automobile purchase than they do in the days and weeks leading up to the purchase. Why? Well, after the purchase they can still remember the many good features of the makes and models of the cars they chose not to buy, and there is still some dissonance, some niggling doubt that maybe they made a wrong choice. So they look at ads that boast about all the good features of the car they recently purchased to further justify their choice, even though the justification comes after the fact.

Another one of Festinger's experiments illustrates the theory, and it also points to its use in persuasion campaigns (Festinger \& Carlsmith, 1959). People were brought into a laboratory and given an exceedingly boring task. Each subject was led to believe that the point of the experiment was to see how people dealt with the stress of a boring manual job, but the real experiment came when they finished. At that point, they were asked if they would help out by telling the next subject waiting outside the lab that the task was actually quite interesting. The experimenter then paid the subject. Some subjects were paid $\$ 1$, others were paid $\$ 20$. The subject then went and told the waiting subject (really a confederate) how interesting the task was before leaving. Some time later, he was asked how interesting/boring the task had actually been.

Now think about it: by using the excuse of needing the subjects to help him, the experimenter induced participants to tell someone that the tasks were very interesting and enjoyable when privately they had found them boring. There was now dissonance between those two pieces of information, but that dissonance could be reduced by changing their private opinion. And some subjects did change their opinion and say that when they looked back on it, the task was really not all that boring. Others said what they really believed: the tasks were boring and dull, and the only reason they had told the waiting subject otherwise was because they were trying to help out the experimenter. But who changed their private opinions? Only those subjects who received the small compensation changed their personal, private views. The people who got $\$ 20$ felt sufficiently compensated, so the fact that their private beliefs and their public behaviour were dissonant was not problematic. But when subjects got only $\$ 1$, the dissonance between their belief and their behaviour was not adequately justified by the reward, so they changed their behaviour in order to achieve dissonance reduction. ${ }^{9}$

Festinger saw this work as important to the study of persuasion, and here is why. If people are trying to reduce dissonance by changing an opinion, they will be very receptive to communications attempting to influence them in that particular direction. For example, if you like sugar but also know that too much sugar is bad for you, you might be in a state of dissonance. That is, your behaviour-eating sugary foods-is not conso-

McCarron, Gary. 2021. Lecture 6: Contemporary Research in Rhetoric/Persuasion. Scholarly and Research Communication, 12(1). doi:10.22230/src.2021v12n1a373
VOLUME 12 / ISSUE 1 / 2021 


\section{Scholarly and Research}

\section{Communication}

VOLUME 12 / ISSUE 1 / 2021 nant with your belief that too much sugar is bad for your health. However, many people find it difficult to give up eating desserts. Thus, when someone mentions to you a study that has shown that the dangers of sugar consumption are greatly overrated, you might be predisposed to accept that the study is true since it allows you to shift your belief in a way that enables you to continue to enjoy sweet foods. The study is particularly persuasive because, in this case, it helps you to reduce the uncomfortable feeling of dissonance. Here is another of Festinger's elegant but simple illustrations of this same point.

Many people believe that they should brush their teeth three times a day, after every meal. However, many, or perhaps most, of the people who believe this do not actually brush their teeth that often. People are often at their workplaces for lunch, and finding time for proper dental hygiene is difficult. Thus, dissonance exists in the discordance between their belief and their actual behaviour. People in this situation, therefore, would be prone to being influenced by a communication that told them it is actually harmful to brush their teeth too often. They would also be persuaded by a message saying that a certain brand of toothpaste is so good that if one uses it, it is only necessary to bush once a day. Either of these communications, if accepted and believed, reduce dissonance. Consequently, a marketing company could exploit existing dissonance by creating a product intended to reduce dissonance. That is, a toothpaste manufacturer could simply claim to have formulated a product that is effective in providing ample dental hygiene even if it is used only once daily. When it is difficult to change your behaviour, you will be more easily persuaded to change your beliefs.

What we see, then, is that the shift from eloquence to scientific management carries with it the potential for increasingly manipulative forms of message production. At the same time, however, we need to be careful about accepting too wholeheartedly the implied vision of human nature that such research presents. If advertising works 50 percent of the time, even though we can never be sure which 50 percent is going to be the successful portion, perhaps we can also suggest that while people are prone to being influenced by messages produced according to social psychological principles, not everyone will be so persuadable - and we may be unable to determine exactly who will be resistant.

\section{Subliminal persuasion}

One final consideration concerns the idea that the empirical transformation of rhetoric

might also include sneaky and deceptive forms of advertising, so-called subliminal persuasion. Beginning in the mid-1950s, popular magazines and leading newspapers began to carry accounts of experiments being conducted during films that were allegedly having dramatic impacts on audience behaviour. Specifically, it was claimed that theatres were running subliminal cuts during movies, very rapid cuts of only a few frames undetectable to the eye, that were supposedly influenced moviegoers. In September of 1957, a heretofore-unknown company called Subliminal Projection, Inc. held a press conference and claimed to have successfully influenced people to buy popcorn and Coke during movie intermissions at a theatre in New Jersey over a six-week period. Once every five seconds, a message flashed on the screen at $1 / 3$,oooth of a second - too fast to be seen by the unaided eye-that led to an 18 percent increase in Coke sales and a whopping 58 percent increase in popcorn sales. ${ }^{10}$ 
Consumer critics were outraged, and dire warnings appeared in major magazines and periodicals across the world. This was at the height of the Cold War, and concerns were particularly high that the Soviet infiltration of the American entertainment industry could spell political and military disaster. The machine that was supposedly capable of projecting such brief messages-invented and patented by James Vicarywould not work with television transmissions, but movies were a perfect place for unscrupulous marketers and even propagandists to reshape American consciousness. In fact, both Britain and Australia passed laws making subliminal persuasion illegal even before it had been properly studied, and bans cropped up in various states across the United States. ${ }^{11}$

The moral panic created by subliminal persuasion did not last, though, as no one could replicate any of the experiments that its original formulators claimed to have performed. However, the fact that it was even considered seriously shows how thoroughly devoted people were to the idea that human behaviour could be engineered-that persuasion was simply a matter of pushing the right buttons or showing people tempting pictures, even at speeds beyond the threshold of their awareness. If there was ever a moment in the history of rhetoric that indicated a shift from humans conceiving of rhetoric as art to thinking of it as a strictly scientific enterprise rooted in the capacity of experts to manipulate our desires and unconscious urges, the age of subliminal persuasion would appear to be it.

In recent years, however, the rise of neurorhetorics has indicated a further attempt to make persuasion accountable to science by suggesting a direct relation between persuasive practice and certain brain centres. Using MRIs, researchers have begun to explore mapping people's brain activity as they process particular kinds of information or engage in certain activities. The next question that has become interesting to rhetoric scholars is whether persuasion is a consequence of how certain forms of information are coded and responded to. ${ }^{12}$

As Michelle Gibbons (2018) suggests, neuroscientific research has flourished over the past several years, as accounts of the latest findings from the different branches of neuroscience are featured regularly in mainstream media. She claims that neuroscientific research into brain activity has "a seductive allure" that has led to the "emergence of various neuro-subfields, such as neuroeconomics, neurolaw, neuroaesthetics, neuroethics" (p. 1), and more. Neurorhetorics, then, is part of a developing program of scientific investigation. Indeed, Gibbons speculates that we inhabit "a now-dominant neuroculture, characterized by the belief in the brain as the originary site of all human activity" (p. 2).

Will neurorhetorics lead to a new understanding of persuasive activity that replaces ethos, pathos, and logos with cognitive activity wholly measurable via brain scanning technologies? Or will neurorhetorics go the way of subliminal persuasion? It is impossible to say, of course. However, neuroscience has already made significant inroads in the study of the arts and humanities, as Gibbons points out. Hence, it would be reasonable to assume that aspects of the neuroscientific approach to persuasion are likely to be integrated in future discussions of the underlying principles of rhetorical practices. 
Scholarly and Research

\section{Communication}

VOLUME 12 / ISSUE 1 / 2021

\section{Notes}

1. One of the more popular critiques of big data is Cathy O'Neill's (2017) Weapons of Math Destruction: How Big Data Increases Inequality and Threatens Democracy.

2. Bacon (1973) said that "the duty and office of rhetoric is to apply reason to imagination for the better moving of the will" (p. 146). In other words, we use reason to keep our imaginations in check and make wiser decisions. For example, our imagination might be captivated by the seductive appeal of a second slice of cake, but our reason intervenes so that our action ("moving of the will") is restrained by rational considerations. It is in this sense that rhetoric, for Bacon, is concerned with self-persuasion.

3. Comte's theory of the stages of civilization was first described in his six-volume work Course on Positive Philosophy, published between 1830 and 1842. In 1848, he published a single volume summarizing his ideas, which appeared in English as $A$ General View of Positivism (Comte, 2015). I recommend this book for those wanting to explore Comte's thought.

4. A lively debate about the consequences of Abraham Flexner's report on the medical profession in North America continues. For a positive account of Flexner's work, see “The Flexner Report: 100 Years Later" by Thomas P. Duffy (2011). A less celebratory view of the report and its aftermath is Elizabeth Hlavinka's (2020) critique of the report's racial biases. While some medical historians have defended Flexner against charges of racism, the American Medical Association issued a public apology in 2008 for the association's promotion of racist policies (Stanley, 2020).

5. In his book Science of Coercion: Communication Research and Psychological Warfare, 1945-1960, Christopher Simpson (1996) argues that a good deal of the research published in Public Opinion Quarterly was commissioned by the government, and that the work that was often paid for by organizations such as the CIA.

6. Useful information concerning Lazarsfeld's research is described by Allen Barton (1979) and Ronald A. Fullerton (1994).

7. I should add that the Bureau of Applied Research was also involved in clandestine research for the government and the United States military. One well-known incident involves political science professor Daniel Lerner, who was asked in 1950 to conduct research sponsored by the government and its radio station, Voice of America, to evaluate the degree to which citizens in six Middle Eastern countries (including Iran) were exposed to the media. The study also analyzed their opinions on local, national, and international affairs and gauged their reactions to international radio broadcasts. The results of the study were published in 1958 under the title The Passing of Traditional Society: Modernizing the Middle East (Lerner, 1958). Lerner suggested that the West provided the only possible model for modernization thanks to the cultural presence of empathy, which was defined as a trait particular to modern men and women. It had enabled Westerners to throw off the yoke of passivity and fatalism, two traits that, he argued, characterized "traditional" Middle Eastern societies. Hence, much of the development ideology that pervaded-and still pervades-Western thinking owes a good deal to research that was carried out by Lerner. The ethnocentrism and occasional racism of such policies was disguised under the veneer of scientific respectability.

McCarron, Gary. 2021. Lecture 6: Contemporary Research in Rhetoric/Persuasion. Scholarly and Research Communication, 12(1). doi:10.22230/src.2021v12n1a373 
8. Barbie made her debut as a female symbol in 1957, after Ruth Handler, who formed the Mattel corporation with her husband, Elliot Handler, designed a doll with a body inspired by Bild Lilli, a German doll that was marketed as a sex toy for men. Ruth and Elliot hired Ernest Dichter, then the director of the Institute for Motivational Research, to market the product, which was named after their daughter. Dichter approached marketing from a methodology informed by Freud's theories. Barbie grew up to become one of the more prominent and lucrative symbols of consumer culture and the American female (see Pearson \& Mullins, 1999).

9. Explanations of many of Festinger's experiments, including the boring test experiment described here, can be found in Eddie Harmon-Jones and Judson Mills (2019).

10. Much of the information about Subliminal Projection, Inc., including the data cited here, is available in "Subliminal Projection: History and Analysis" by Thomas Albert Bliss (1983). Additional information about this research can also be found in Freud on Madison Avenue: Motivation Research and Subliminal Advertising in America by Lawrence R. Samuel (2010).

11. James Vicary later admitted that the experimental data he presented were falsified. Nonetheless, interest in subliminal persuasion continues to this day. A good overview of Vicary's career, including an extensive account of the rise of subliminal messaging generally, is Charles Acland's (2011) excellent book Swift Viewing: The Popular Life of Subliminal Influence.

12. The journal Rhetoric Society Quarterly focused on neurorhetorics in a special issue in 2010. See, in particular, Jordynn Jack's (2010) introductory article, "What is Neurorhetorics?" A more recent effort in applying neuroscience to rhetoric is Michelle Gibbons' (2018) article "A Neurorhetorics of Incongruity," which relies to a considerable extent on the work of Kenneth Burke.

\section{References}

Acland, Charles. (2011). Swift viewing: The popular life of subliminal influence. Durham, NC: Duke University Press.

Bacon, Francis. (1973). The advancement of learning. London, UK: J.M. Dent \& Sons. (Originally published in 1605.)

Barton, Allen. (1979). Paul Lazarsfeld and applied social research. Social Science History, 3(3-4), 4-44. Bernays, Edward. (1923). Crystallizing public opinion. New York, NY: Gildan Media.

Bliss, Thomas Albert. (1983). Subliminal projection: History and analysis. Hastings Communication and Entertainment Law Journal, 5(3), 419-441. URL: https://repository.uchastings.edu/hastings _comm_ent_law_journal/vol5/iss3/1 [September 15, 2020].

Cantril, Hadley. (1982). The invasion from Mars. Princeton, NJ: Princeton University Press. (Originally published in 1940)

Comte, Auguste. (2015). General view of positivism (J.H. Bridges, Trans.). New York, NY: Routledge. (Originally published in 1865)

Duffy, Thomas P. (2011). The Flexner Report: 100 years later. Yale Journal of Biology and Medicine, $84(3), 269-276$.

Festinger, Leon. (1956). When prophecy fails: A social and psychological study of a modern group that predicted the destruction of the world. New York, NY: Harper \& Row.

Festinger, Leon. (1957). A theory of cognitive dissonance. Stanford, CA: Stanford University Press.
Scholarly and Research

VOLUME 12 / ISSUE 1 / 2021 


\section{Scholarly and Research}

\section{Communication}

VOLUME 12 / ISSUE 1 / 2021
Festinger, Leon, \& Carlsmith, James M. (1959). Cognitive consequences of forced compliance. The Journal of Abnormal and Social Psychology, 58(2), 203-210.

Fullerton, Ronald A. (1994). Tea and the Viennese: A pioneering episode in the analysis of consumer behavior. Advances in Consumer Research, 21, 418-421.

Gibbons, Michelle. (2018). A neurorhetorics of incongruity. Poroi: An Interdisciplinary Journal of Rhetorical Analysis and Invention, 13(2), 1-24.

Harmon-Jones, Eddie, \& Mills, Judson. (2019). An introduction to cognitive dissonance theory and an overview of current perspectives on the theory. In E. Harmon-Jones (Ed.), Cognitive dissonance: Re-examining a pivotal theory in psychology (pp. 3-24). Washington, DC: American Psychological Association. doi:10.1037/0000135-001

Hlavinka, Elizabeth. (2020, June 18). Racial bias in Flexner Report permeates medical education today. MedPage. URL: https://www.medpagetoday.com/publichealthpolicy/medicaleducation /87171 [July 28, 2021].

Jack, Jordynn. (2010). What is neurorhetorics? Rhetoric Society Quarterly, 40(10), 405-410.

Lasswell, Harold. (1927). Propaganda technique in the World War. Boston, MA: MIT Press.

Lasswell, Harold. (1948). The structure and function of communication in society. In L. Bryson (Ed.), The communication of ideas (pp. 37-51). New York, NY: Harper and Row.

Le Bon, Gustave. (2002). Behaviour of crowds. New York, NY: Dover Publications. (Originally published in 1895)

Lerner, Daniel. (1958). The passing of traditional society: Modernizing the Middle East. Glencoe, IL: The Free Press.

McDougall, William. (1920). The group mind. Project Gutenberg. URL: https://www.gutenberg.org /files/40826/40826-h/40826-h.htm [November 12, 2018].

O’Neill, Cathy. (2017). Weapons of math destruction: How big data increases inequality and threatens democracy. New York, NY: Crown Books.

Pavlov, Ivan P. (2015). Conditioned reflexes: An investigation of the physiological activity of the cerebral cortex (G. Anrep, Trans.). Eastford, CT: Martino Fine Books. (Originally published in 1927)

Pearson, Marlys, \& Mullin, Paul R. (1999, December). Domesticating Barbie: An archaeology of Barbie material culture and domestic ideology. International Journal of Historical Archaeology, 3(4), 225-259.

Rogers, Everett M. (1962). Diffusion of innovation (5th ed.). New York, NY, \& London, UK: Free Press.

Samuel, Lawrence R. (2010). Freud on Madison Avenue: Motivation research and subliminal advertising in America. Philadelphia, PA: University of Pennsylvania Press.

Simpson, Christopher. (1996). Science of coercion: Communication research and psychological warfare, 1945-1960. Oxford, UK: Oxford University Press.

Stanley, Ben. (2020, June 16). “They force action by crisis”: The story behind the American Medical Association's 2009 apology for holding back black medicine. The Rotation. URL: https://the-rotation.com/they-force-action-by-crisis-the-story-behind-the-american-medical-associations-2008-apology-for-holding-back-black-medicine/ [July 1, 2021].

Watson, John B. (1913). Psychology as the behaviorist sees it. Psychological Review, 20(2), 158-177. 